\title{
Factors Influencing Lung Function in Patients with Cystic Fibrosis in Western Romania
}

\author{
Mihaela Dediu ${ }^{1-3}$ \\ loana Mihaiela Ciuca (D) ${ }^{1-3}$ \\ Monica Steluta Marc iD ${ }^{4}$ \\ Estera Boeriu (D) \\ Liviu Laurentiu Pop' \\ 'Pediatric Department, University of \\ Medicine and Pharmacy "Victor Babes", \\ Timisoara, Romania; ${ }^{2}$ National Cystic \\ Fibrosis Centre, Timisoara, Romania; \\ 3"Pius Branzeu" County Hospital, \\ Timisoara, Romania; ${ }^{4}$ Pulmonology \\ Department, University of Medicine and \\ Pharmacy "Victor Babes", Timisoara, \\ Romania
}

Purpose: The aim of this cross-sectional study was to identify the major factors influencing pulmonary function in CF patients from western side of Romania.

Patients and Methods: The study enrolled 51 patients with CF between the ages of 6 and 27.8 years who were monitored at regular visits to the National Cystic Fibrosis Centre and Pius Branzeu County Hospital in Timisoara, Romania, over a period of 2 years. The relationships between lung function, as measured by forced expiratory volume in 1 $\mathrm{s}\left(\mathrm{FEV}_{1}\right)$, with patient age, sex, body mass index (BMI), pancreatic insufficiency (PI), microbial infection, CF-related diabetes (CFRD), CF-associated liver disease (CFLD), and physical activity $<30 \mathrm{~min} /$ day, were evaluated by multivariate regression analysis.

Results: The results showed that FEV1 was $0.32 \%$ higher for each increase in percentile of BMI (95\% confidence interval: 0.034-0.619). In addition, mean $\mathrm{FEV}_{1}$ was $1.52 \%$ lower with every year rise of age. PI and female sex increased the risk of impaired lung function (FEV $<60 \%$ ). The factors most closely correlated with pulmonary function in pediatric CF patients were current age (negative) and BMI (positive).

Conclusion: The findings of this study, in combination with what is known from other studies in $\mathrm{CF}$, suggest that a better nutritional status and infection prophylaxis should be part of a comprehensive clinical management strategy for pediatric CF in Romania.

Keywords: cystic fibrosis, pediatric, respiratory disease, cystic fibrosis outcome

\section{Introduction}

Cystic fibrosis (CF) is an autosomal recessive genetic disease in children ${ }^{1}$ that has serious adverse impacts on patients' quality of life and life expectancy. ${ }^{2} \mathrm{CF}$ is the most common potentially lethal monogenic disease in the Caucasian population and has variable clinical presentation, ${ }^{3}$ but usually progresses to chronic obstructive pulmonary disease with frequent pulmonary infections, ${ }^{4}$ chronic steatorrhea associated with exocrine pancreatic insufficiency (PI), liver disease or secondary diabetes. $^{5}$ Osteopathy, nasal polyposis, chronic sinusitis, obstructive azoospermia, ${ }^{2,6}$ meconium ileus, rectal prolapse, and salt loss syndrome are possible manifestations or complications of $\mathrm{CF}^{7}$

Lung disease is the major problem associated with $\mathrm{CF}$ in terms of prognosis and management. ${ }^{8}$ The clinical course of $\mathrm{CF}$ is influenced by frequent pulmonary exacerbations that cause structural and functional damage to the lungs, ${ }^{9}$ highlighting the importance of therapeutic interventions that preserve lung function. ${ }^{4}$ Factors affecting pulmonary function include patient age, body mass index (BMI) ${ }^{10,11}$ female sex, PI, ${ }^{12,13}$ CF-related diabetes (CFRD), CF-associated liver disease $(\mathrm{CFLD}),{ }^{12}$ and respiratory bacterial infections ${ }^{14}$ requiring repeated and long courses
Correspondence: loana Mihaiela Ciuca Pediatric Department, University of Medicine and Pharmacy "Victor Babes", Timisoara, Romania

Tel +40744513283

$\mathrm{Fax}+40356494529$

Email ciuca.ioana@umft.ro 
of antibiotics. ${ }^{15}$ Because of a lack of neonatal screening in Romania, CF patients are diagnosed late, subsequently fail to thrive, and have an increased frequency of chronic infections in addition to altered lung function. A good clinical outcome for $\mathrm{CF}$ depends on improving lung function, which is difficult to achieve in Romania in the absence of modulator therapies. Considering that Romanian CF patients require a complete evaluation, the effect of factors influencing the lung function of our patients turn out to be important to be assessed. This was addressed in a cross-sectional study of a cohort of CF patients who were monitored over a 2-year period at the National Cystic Fibrosis Centre and Pius Branzeu County Hospital in Timisoara, Romania.

\section{Materials and Methods}

\section{Patients}

From May 2017 to June 2019, CF patients from Western Romania who regularly visited the National Cystic Fibrosis Centre in Romania were screened for eligibility to participate in the study. The inclusion criteria were as follows: patients with typical CF who were capable of performing the spirometry test, were not experiencing pulmonary exacerbation, and regularly visited the center. Patients who suffered an exacerbation in the last 3 months were not included. Patients and their guardians consented in writing to the use of their data for research purposes. The study was conducted in accordance with the principles of the Declaration of Helsinki, and was approved by the Ethics Committee of Pius Branzeu County Hospital (1145/ 2016).

\section{Data Collection}

At the time of study enrollment, we measured patients' weight and height to calculate BMI according to US Centers for Disease Control and Prevention percentiles, ${ }^{16}$ collected bacteriologic samples, and carried out screening for CFLD and CFRD in accordance with national guidelines. Based on self-reported physical activity levels, the patients were classified as active ( $\geq 30 \mathrm{~min} /$ day of physical activity) or sedentary (physical activity for $<30 \mathrm{~min} /$ day). Pulmonary function was assessed by spirometry; forced expiratory volume in $1 \mathrm{~s}\left(\mathrm{FEV}_{1}\right)$ was recorded as parameter related to lung function. $\mathrm{FEV}_{1}$ was used as the main index of lung function, and the best $\mathrm{FEV}_{1}$ value in each year was recorded for reference and categorized as follows: $>80 \%$, no obstruction (normal); $80-60 \%$, mild obstruction; $40-$
$59 \%$, moderate obstruction and $<40 \%$, severe obstruction. No other $\mathrm{FEV}_{1}$ value was monitored in this study. Spirometry was performed outside of periods of exacerbation according to American Thoracic Society/European Respiratory Society standards, with Global Lung Function Initiative 2012 reference equations used to calculate predicted parameter values. ${ }^{17}$ Data on age at diagnosis of $\mathrm{CF}$, Pseudomonas infection status and PI, also the patients genotypes were obtained from the center's medical records.

\section{Data Analysis}

Multivariate regression analysis was performed to predict whether patient characteristics influence $\mathrm{FEV}_{1}$. The independent variables were current age, age at $\mathrm{CF}$ diagnosis, BMI, Pseudomonas aeruginosa infection, methicillinresistant Staphylococcus aureus (MRSA) infection, PI, CFRD, CFLD, and physical activity. Quantitative data are expressed as mean \pm standard deviation (SD) for continuous variables and as counts and percentages for categorical variables. Kolmogorov-Smirnov test was utilized to determinate the parametric and non-parametric data distribution and Mann-Whitney $U$-test, chi-square test and $t$-independent test were used to compare differences between the subgroups. To test the averages between two independent groups Mann-Whitney $U$-test (non-parametric data) was applied and $t$-independent test (parametric data). Chisquare test was used for comparison between independent groups with binomial data. Adjusted odds ratios (ORs) or risk ratios (RRs) with 95\% confidence intervals (CIs) were calculated by univariate associations between patients with different outcomes and each predictor separately. Statistical analyses were performed with SPSS v20.0 for Windows (SPSS Inc, Chicago, IL, USA). A P value $<0.05$ was considered significant.

\section{Results}

\section{Characteristics of the Study Population}

A total of 51 patients aged between 6 and 27.8 years of age (mean \pm SD: $13.7 \pm 5.7$ years) were enrolled in the study. The characteristics of the patients are shown in Table 1. Most patients $(89.5 \%)$ were clinically underweight, and the mean BMI percentile $( \pm \mathrm{SD}$ ) was $19.2 \pm 22.1$ (normal: 5 th to 85 th percentile). There was a slight majority of male patients (54.9\%). A significant prevalence of F508del mutation exists in our population, as $52.9 \%$, children were homozygous for F508del CFTR mutation, followed by $38 \%$ of compound heterozygous F508del/nonF508del and 9.1\% with another 
Table I Characteristics of Patients by Age Category

\begin{tabular}{|c|c|c|c|c|}
\hline Characteristic & All Patients $(n=51)$ & Age 6-12 Years $(n=25)$ & Age I2-18 Years $(n=15)$ & Age $>18$ Years $(n=I I)$ \\
\hline \multicolumn{5}{|l|}{ Sex } \\
\hline Female & $23(45.1)$ & $10(40)$ & $7(46.7)$ & $6(54.5)$ \\
\hline Male & $28(54.9)$ & $15(60)$ & $8(53.3)$ & $5(45.5)$ \\
\hline Current age & $13.79 \pm 5.76$ & $9.36 \pm 1.92$ & $14.58 \pm 2.16$ & $22.76 \pm 3.54$ \\
\hline Age at CF diagnosis & $4.49 \pm 4.91$ & $1.98 \pm 2.16$ & $4.45 \pm 4.31$ & $10.27 \pm 5.54$ \\
\hline $\mathrm{BMI} \mathrm{kg} / \mathrm{m}^{2}($ mean $\pm \mathrm{SD})$ & $|6.32 \pm 2.6|$ & $15.28 \pm 2.49$ & $17.02 \pm 2.07$ & $17.67 \pm 2.77$ \\
\hline BMI percentile & $19.27 \pm 22.19$ & $24.52 \pm 24.58$ & $21.6 \pm 20.58$ & $4.18 \pm 9.61$ \\
\hline $\mathrm{FEV}_{1}, \%$ & $76 \pm 21.32$ & $82.92 \pm 15.82$ & $70.27 \pm 23.91$ & $68.09 \pm 14.16$ \\
\hline \multicolumn{5}{|l|}{ Chronic infection } \\
\hline Pseudomonas & $27(52.9)$ & $10(40)$ & $8(53.3)$ & $9(8 \mathrm{I} .8)$ \\
\hline MRSA & $10(19.6)$ & $6(24)$ & $2(13.3)$ & $2(18.2)$ \\
\hline Pancreatic insufficiency & $42(82.4)$ & $22(88)$ & $12(80)$ & 8 (72.7) \\
\hline CFLD & $28(54.9)$ & II (44) & II (73.3) & $6(54.5)$ \\
\hline CFRD & $5(9.8)$ & I (4) & I (6.7) & $3(27.3)$ \\
\hline Physical activity $<30 \mathrm{~min} /$ day & $21(4 \mid .2)$ & II (44) & $6(40)$ & $4(36.4)$ \\
\hline
\end{tabular}

Notes: Data are presented as mean \pm standard deviation or $\mathrm{n}(\%)$ unless otherwise indicated.

Abbreviations: BMI, body mass index; CF, cystic fibrosis; CFLD, cystic fibrosis-associated liver disease; CFRD, cystic fibrosis-related diabetes; FEV ${ }_{1}$, forced expiratory volume in I s; MRSA, methicillin-resistant Staphylococcus aureus.

genotype. The mean $\mathrm{FEV}_{1}( \pm \mathrm{SD})$ was $76 \% \pm 21.3 \%$ (range: $33-127 \%)$.

\section{Multivariate Regression Analysis of Patient Factors Influencing Pulmonary Function}

Multivariate regression analysis was performed to predict whether patient characteristics influence $\mathrm{FEV}_{1}$. The independent variables were current age, age at $\mathrm{CF}$ diagnosis, BMI, Pseudomonas aeruginosa infection, methicillin-resistant Staphylococcus aureus (MRSA) infection, PI, CFRD, CFLD, and physical activity. These factors explained $30 \%$ of the variability in the $\mathrm{FEV}_{1}$ value $\left(\mathrm{r}^{2}=0.301\right)$. The results of the multivariate regression analysis are summarized in Table 2 .

The regression model revealed a significant effect of patients' current age $(\mathrm{P}=0.04)$ and $\mathrm{BMI}(\mathrm{P}=0.03)$ on lung function: average $\mathrm{FEV}_{1}$ was $1.52 \%$ lower for higher ages (95\% CI: -2.98 to -0.06 ). Although a negative association was found between current age and FEV1 $(B=-1.52$, $\mathrm{p}=$ 0.04 ), almost the same association was observed between age at $\mathrm{CF}$ diagnosis and FEV1 value but in a positive way $(\mathrm{B}=$ $1.52, p=0.081$ ), with no statistical significance. The relationship between BMI and $\mathrm{FEV}_{1}$ was positive: a higher BMI was associated with a higher average FEV1\%; mean $\mathrm{FEV}_{1}$ was
$0.32 \%$ higher for each percentile of BMI (95\% confidence interval: $0.03-0.61)$. No significant correlations were found between age at $C F$ diagnosis $(p=0.081), P$. aeruginosa $(p=$ 0.09), MRSA infection ( $\mathrm{p}=0.841), P I(\mathrm{p}=0.942), \mathrm{CFRD}(\mathrm{p}=$ $0.244)$, CFLD $(p=0.983)$, or decreased physical activity $(\mathrm{p}=0.784)$ and lung function (Table 2$)$.

\section{Risk Factors for Pulmonary Dysfunction in Pediatric CF}

Nearly half of patients (49.01\%) had good lung function $\left(\mathrm{FEV}_{1}>80 \%\right.$ ) (Table 3). Patients with moderate or severe obstruction $\left(\mathrm{FEV}_{1}<60 \%\right)$ were diagnosed with $\mathrm{CF}$ at a later age ( $6.7 \pm 4.7$ years) than those with mild obstruction ( $\mathrm{FEV}_{1}=60-80 \% ; 3.02 \pm 3.7$ years) or normal lung function $\left(\mathrm{FEV}_{1}>80 \% ; 4.4 \pm 5.3\right.$ years). Additionally, the percentage of patients with chronic Pseudomonas infection was higher in the $\mathrm{FEV}_{1}<60 \%$ group $(72.7 \%)$ compared to the group with normal lung function $(40 \%)$. Evaluating the subgroup patients with FEV1 $<60 \%$, we noticed that more than half of patients (54.5\%) were F508 homozygous, another $36.4 \%$ heterozygous for F508, a significant predominance of $90 \%$ for F508del mutation. Only $9.1 \%$ of patients with impaired lung function had non F508del genotypes. 
Table 2 Results of the Multivariate Regression Analysis of the Effects of Different Variables on FEVI

\begin{tabular}{|c|c|c|c|c|c|c|c|}
\hline \multirow[t]{3}{*}{ Variable } & \multirow{2}{*}{\multicolumn{2}{|c|}{$\begin{array}{l}\text { Unstandardized } \\
\text { Coefficients }\end{array}$}} & \multirow{3}{*}{$\begin{array}{l}\text { Standardized } \\
\text { Coefficient } \\
\text { B }\end{array}$} & \multirow[t]{3}{*}{$t$} & \multirow[t]{3}{*}{ Significance } & \multicolumn{2}{|c|}{$95 \% \mathrm{Cl}$ for $\mathrm{B}$} \\
\hline & & & & & & \multirow{2}{*}{$\begin{array}{l}\text { Lower } \\
\text { Bound }\end{array}$} & \multirow{2}{*}{$\begin{array}{l}\text { Upper } \\
\text { Bound }\end{array}$} \\
\hline & B & SE & & & & & \\
\hline (Constant) & 87.976 & 14.258 & & 6.170 & 0.000 & 59.15 & 116.79 \\
\hline Sex & 2.698 & 6.578 & 0.064 & 0.410 & 0.684 & -10.5 & 15.99 \\
\hline Current age & -1.524 & 0.724 & -0.412 & -2.104 & 0.042 & -2.98 & -0.06 \\
\hline Age at CF diagnosis & 1.521 & 0.849 & 0.350 & 1.790 & 0.081 & -0.19 & 3.23 \\
\hline BMI percentile & 0.327 & 0.145 & 0.340 & 2.253 & 0.030 & 0.034 & 0.61 \\
\hline $\begin{array}{l}\text { Chronic Pseudomonas } \\
\text { infection }\end{array}$ & -11.213 & 6.464 & -0.265 & -1.735 & 0.090 & -24.27 & 1.85 \\
\hline Chronic MRSA infection & -1.524 & 7.539 & -0.029 & -0.202 & $0.84 I$ & -16.76 & $|3.7|$ \\
\hline Pancreatic insufficiency & 0.662 & 9.080 & 0.012 & 0.073 & 0.942 & -17.68 & 19.01 \\
\hline CFLD & -0.150 & 7.018 & -0.004 & -0.021 & 0.983 & -14.33 & 14.03 \\
\hline CFRD & 10.059 & 10.503 & 0.142 & 0.958 & 0.344 & -11.16 & 31.28 \\
\hline Physical activity $<30 \mathrm{~min} /$ day & -1.895 & 6.860 & -0.044 & -0.276 & 0.784 & -15.75 & 11.96 \\
\hline
\end{tabular}

Abbreviations: BMI, body mass index; CF, cystic fibrosis; CFLD, cystic fibrosis-associated liver disease; CFRD, cystic fibrosis-related diabetes; Cl, confidence interval; FEVI, forced expiratory volume in I s; MRSA, methicillin-resistant Staphylococcus aureus; SE, standard error.

There were statistically significant differences between patients with $\mathrm{FEV}_{1}<60 \%$ and those with normal lung function in terms of current age 18.6 years versus 12.8 years $(\mathrm{P}=0.008)$ and $\mathrm{BMI}$ percentile $(\mathrm{P}=0.041)$. Patients with $\mathrm{FEV}_{1}<60 \%$ had a lower BMI percentile than those with $\mathrm{FEV}_{1}>80 \%(9 \pm 12.3$ vs $25.2 \pm 24.6)$ and were older (18.6 \pm 6.2 vs $12.86 \pm 5.3$ years). The mean $\mathrm{FEV}_{1}$ in patients with moderate or severe obstruction was almost half the value of those with normal lung function $(44 \% \pm 7.05 \%$ vs $93.3 \% \pm 10.3 \%)$. About onefifth of patients $(21.56 \%)$ had moderate or severe obstruction; associated factors included chronic Pseudomonas infection, female sex, and physical activity $<30 \mathrm{~min} /$ day. Patients with chronic Pseudomonas infection were at 2.3 times higher risk for poor lung function $\left(\mathrm{FEV}_{1}\right.$ $<60 \%$ ) than uninfected children (Table 4).

PI, female sex, F508 del homozygous genotype and physical activity $<30 \mathrm{~min} /$ day increased the risk for $\mathrm{FEV}_{1}$ $<60 \%$ (RR for $\mathrm{PI}=1.75,95 \% \mathrm{CI}$ : 0.57 to 0.53 ; RR for female sex $=1.46,95 \%$ CI: 0.51 to 4.17 ; RR for F508del $=1.09$ 95\% CI: $0.11-11.8$ and RR for physical activity $<30$ $\mathrm{min} / \mathrm{day}=1.22,95 \% \mathrm{CI}: 0.41$ to 3.66 ) (Table 4). Chronic MRSA infection ( $R R=1.09,95 \% \mathrm{CI}: 0.27$ to 4.3 ) and CFRD ( $R R=1.08,95 \%$ CI: 0.17 to 6.82 ) had a weak influence on the probability of $\mathrm{FEV}_{1}<60 \%$, but CFLD was not a risk factor $(\mathrm{RR}=0.69)$.

Chronic Pseudomonas infection was present in 52.9\% of the patients; these patients had a significantly lower $\mathrm{FEV}_{1}$ than those without infection $(70.8 \pm 23.8$ vs 81.7 \pm 16.7 ) (Table 5), and almost similar BMI (20.3 compared to 18.08). The rate of chronic Pseudomonas infection was higher in females (OR=1.79, 95\% CI: 0.58 to 5.49$)$ and in patients with impaired lung function $\left(\mathrm{FEV}_{1}<80 \%\right.$; $\mathrm{OR}=2.83,95 \% \mathrm{CI}: 0.9$ to 8.83 ).

\section{Discussion}

This is the first study evaluating factors affecting lung function in Romanian pediatric patients with cystic fibrosis presenting the relation of different risk factors with the lung function. The lack of neonatal screening in Romania associates a delayed diagnosis, when secondary complications like failure to thrive and chronic infections alter lung function. FEV1 is an important parameter in the evaluation of lung function. ${ }^{18}$ The FEV $_{1}$ values in our cohort varied, ranging from severe obstruction $\left(\mathrm{FEV}_{1}<40 \%\right)$ in a few patients to a relatively normal value of $78 \%$. Moderate or severe obstruction was observed in a substantial proportion of our patients (21.56\%), indicating that intervention was urgently needed. 
Table 3 Characteristics of Patients by FEV , Category

\begin{tabular}{|c|c|c|c|}
\hline Characteristic & $\begin{array}{l}\mathrm{FEV}_{1}<60 \%^{\mathrm{a}} \\
(\mathrm{n}=\mathrm{II})\end{array}$ & $\begin{array}{l}\mathrm{FEV}_{1}=60 \%-80 \% \mathrm{~b} \\
(\mathrm{n}=15)\end{array}$ & $\begin{array}{l}\mathrm{FEV}_{1}>80 \%^{\mathrm{c}} \\
(\mathrm{n}=25)\end{array}$ \\
\hline Sex & & & \\
\hline Female & $6(54.5)$ & $7(46.7)$ & $10(40)$ \\
\hline Male & $5(45.5)$ & $8(53.3)$ & $15(60)$ \\
\hline Current age & $18.62 \pm 6.28$ & $11.79 \pm 4.22$ & $12.86 \pm 5.32$ \\
\hline $\begin{array}{l}\text { Age at } \mathrm{CF} \\
\text { diagnosis }\end{array}$ & $6.7 \pm 4.72$ & $3.02 \pm 3.76$ & $4.41 \pm 5.39$ \\
\hline BMI percentile & $9 \pm 12.39$ & $16.8 \pm 21.29$ & $25.28 \pm 24.65$ \\
\hline $\mathrm{FEV}_{1}, \%$ & $44 \pm 7.05$ & $70.53 \pm 5.48$ & $93.36 \pm 10.33$ \\
\hline Chronic infection & & & \\
\hline Pseudomonas & $8(72.7)$ & $9(60)$ & $10(40)$ \\
\hline MRSA & $2(18.2)$ & $3(20)$ & $5(20)$ \\
\hline $\begin{array}{l}\text { Pancreatic } \\
\text { insufficiency }\end{array}$ & $8(72.7)$ & $15(100)$ & $19(76)$ \\
\hline CFLD & $7(63.6)$ & $8(53.3)$ & $13(52)$ \\
\hline CFRD & I (9.1) & I (6.7) & $3(12)$ \\
\hline $\begin{array}{l}\text { Physical activity } \\
<30 \mathrm{~min} / \text { day }\end{array}$ & $4(36.4)$ & $8(53.3)$ & $9(36)$ \\
\hline
\end{tabular}

Notes: Data are presented as mean \pm standard deviation or $\mathrm{n}(\%)$ unless otherwise indicated. a'Moderate to severe obstruction; 'Mild obstruction; 'No obstruction (normal lung function).

Abbreviations: BMI, body mass index; CF, cystic fibrosis; CFLD, cystic fibrosisassociated liver disease; CFRD, cystic fibrosis-related diabetes; FEV ${ }_{1}$, forced expiratory volume in I s; MRSA, methicillin-resistant Staphylococcus aureus.

We investigated whether factors known to influence lung function in $\mathrm{CF}$ would be significant in our pediatric cohort using a multivariate regression model. PI had no influence on lung function ( $\mathrm{P}=0.942$, Table 2), possibly because most of our patients had PI, which is typical in classic forms of $\mathrm{CF} .{ }^{19}$ In the general study population, using the multivariate regression model, no statistical influence of PI was found $(\mathrm{p}=0.92)$ on the FEV1 of all patients, as the combined effect of all factors included in the multivariate model was assessed. Yet, the calculation of the risk factors for the subgroup of patients with lower FEV $1<60 \%$ showed that patients with PI have a higher risk of 1.75 RR for a lower pulmonary function. Physical activity level had no significant effect on $\mathrm{FEV}_{1}$ in our multivariate analysis, although increased activity has been shown to improve clinical outcome in $\mathrm{CF}$ patients. ${ }^{20}$ Nevertheless, the physical activity $<30 \mathrm{~min} /$ day associate an impaired lung function of $\mathrm{FEV}_{1}<60 \%$ $(\mathrm{RR}=1.22,95 \% \mathrm{CI}: 0.41$ to 3.66$)$, revealing thar low $\mathrm{FEV}_{1}$ is associated with a decrease activity level because of fatigability. Also, the F508 del homozygous genotype was a risk factor among patients with $\mathrm{FEV} 1<60 \%$, as expected and similar with previous other studies. ${ }^{12,13}$

However, we observed significant relationships between patients' BMI $(\mathrm{P}=0.03)$, current age $(\mathrm{P}=0.04)$ and lung function, evaluated by multivariate regression analysis, consistent with previous findings. ${ }^{12,21}$ Nearly all of our patients (almost 90\%) were underweight (BMI $<20 \mathrm{~kg} / \mathrm{m}^{2}$ ), with low mean BMI percentile of 19.27 \pm 22.19 ; although we intended to carry out a weight gain intervention, none of our patients accepted enteral nutrition because of anxiety pertaining to gastrostomy. The link

Table 4 Relative Risk and Odds Ratio for FEV $<<60 \%$

\begin{tabular}{|c|c|c|c|c|c|c|}
\hline \multirow[t]{2}{*}{ Variable } & \multirow[t]{2}{*}{$\mathbf{R R}$} & \multicolumn{2}{|l|}{$95 \% \mathrm{Cl}$} & \multirow[t]{2}{*}{ OR } & \multicolumn{2}{|l|}{$95 \% \mathrm{Cl}$} \\
\hline & & Lower Bound & Upper Bound & & Lower Bound & Upper Bound \\
\hline Female sex & 1.46 & 0.51 & 4.17 & 1.62 & 0.42 & 6.21 \\
\hline F508 allele & 1.09 & 0.17 & 6.82 & 1.11 & 0.11 & 11.08 \\
\hline Chronic Pseudomonas infection & 2.37 & 0.7 & 7.93 & 2.94 & 0.68 & 12.75 \\
\hline Chronic MRSA infection & 1.09 & 0.27 & 4.30 & 1.12 & 0.20 & 6.26 \\
\hline Pancreatic insufficiency & 1.75 & 0.57 & 5.33 & 2.12 & 0.43 & 10.37 \\
\hline CFLD & 0.69 & 0.23 & 2.08 & 0.63 & 0.15 & 2.50 \\
\hline CFRD & 1.08 & 0.17 & 6.82 & 1.11 & 0.11 & 11.08 \\
\hline Physical activity $<30 \mathrm{~min} /$ day & 1.22 & 0.41 & 3.66 & 1.29 & 0.32 & 5.13 \\
\hline
\end{tabular}

Abbreviations: CFLD, cystic fibrosis-associated liver disease; CFRD, cystic fibrosis-related diabetes; Cl, confidence interval; FEVI, forced expiratory volume in I s; MRSA, methicillin-resistant Staphylococcus aureus; OR, odds ratio; RR, relative risk. 
Table 5 Characteristics of Patients with Chronic Pseudomonas Infection and Uninfected Patients

\begin{tabular}{|c|c|c|c|}
\hline \multirow[t]{2}{*}{ Characteristic } & \multicolumn{2}{|c|}{ Pseudomonas Infection } & \multirow[t]{2}{*}{$\mathrm{p}$ value } \\
\hline & Yes $(n=27)$ & No $(n=24)$ & \\
\hline \multicolumn{4}{|l|}{ Sex } \\
\hline Female & $14(51.9)$ & $9(37.5)$ & 1 \\
\hline Male & $13(48.1)$ & $15(62.5)$ & 1 \\
\hline Current age & $15.26 \pm 6.12$ & $12.13 \pm 4.95$ & 0.057 \\
\hline Age at CF diagnosis & $5.88 \pm 5.68$ & $2.93 \pm 3.33$ & 0.1 \\
\hline BMI percentile & $20.33 \pm 23.43$ & $18.08 \pm 21.14$ & 0.992 \\
\hline $\mathrm{FEV}_{1}, \%$ & $70.85 \pm 23.83$ & $81.79 \pm 16.72$ & 0.042 \\
\hline Chronic MRSA infection & $6(22.2)$ & $4(16.7)$ & 0.444 \\
\hline Pancreatic insufficiency & $23(85.2)$ & $19(79.2)$ & 0.421 \\
\hline CFLD & $18(66.7)$ & $10(41.7)$ & 0.076 \\
\hline CFRD & $3(11.1)$ & $2(8.3)$ & 0.742 \\
\hline Physical activity $<30 \mathrm{~min} /$ day & II (40.7) & $10(41.7)$ & 0.947 \\
\hline
\end{tabular}

Notes: Data are presented as mean \pm standard deviation or $\mathrm{n}(\%)$ unless otherwise indicated.

Abbreviations: BMI, body mass index; CFLD, cystic fibrosis-associated liver disease; CFRD, cystic fibrosis-related diabetes; $\mathrm{FEV}_{1}$, forced expiratory volume in I s; MRSA, methicillin-resistant Staphylococcus aureus.

between nutritional status and lung function has been previously reported by several studies, ${ }^{22,23}$ with a higher BMI being associated with better lung function. ${ }^{12}$

Although it was previously demonstrated that earlier diagnosis has better outcomes for patients with $\mathrm{CF}^{12}$ in our study, age at diagnosis was unrelated to $\mathrm{FEV}_{1}(\mathrm{P}=0.081$, Table 2). However, the current age of patients was negatively correlated with $\mathrm{FEV}_{1}$ that is, older patients had worse lung function. Indeed, mean $\mathrm{FEV}_{1}$ was $1.52 \%$ lower $(95 \% \mathrm{CI}$ : -2.98 to -0.06 ) for every 1 -year of age, in agreement with earlier findings. ${ }^{23,24}$ Thus, older and thinner children are at greater risk for poor lung function, with a mean $\mathrm{FEV}_{1}$ value that is half of that in younger patients with normal BMI.

Chronic Pseudomonas infection was present in more than half of our patients and was associated with a lower $\mathrm{FEV}_{1}$ compared to uninfected patients. Chronic Pseudomonas infection, PI, female sex, and physical activity $<30 \mathrm{~min} /$ day were significant risk factors for $\mathrm{FEV}_{1}$ $<60 \%$, as reported in other studies. ${ }^{12,17,22}$ Differing to published observations, we did not find any association between CFRD $^{12,23}$ or MRSA infection ${ }^{25-27}$ and lung function in our cohort, although female patients with PI and chronic Pseudomonas infection had a higher risk of $\mathrm{FEV}_{1}<60 \%$, as previously reported. ${ }^{28} \mathrm{~A}$ possible explanation for these discrepancies is the small sample size of our study or, in the case of MRSA infection, the prevalence of a less aggressive MRSA strain in our patients than that described by others. ${ }^{29}$ The clinical and functional outcome of $\mathrm{CF}$ patients was found to decline after the development of diabetes, ${ }^{30}$ but in our study CFRD was unrelated to $\mathrm{FEV}_{1}(\mathrm{P}=0.344)$ in the multivariate regression analysis and was not a significant risk factor ( $R R=1.08$, Table 4) for poor lung function. The same was true for CFLD, which did not have a significant effect on $\mathrm{FEV}_{1}(\mathrm{P}=0.983$, Table 2$)$ or constitute a risk factor for $\mathrm{FEV}_{1}<60 \%(\mathrm{RR}=0.69)$, although it is known to affect the life expectancy of CF patients. ${ }^{5}$

\section{Conclusion}

In conclusion, the results of our study demonstrate that patients' BMI and current age had a significant association with FEV1 in our patients. We also identified chronic Pseudomonas infection, PI, female sex, and physical activity $<30 \mathrm{~min} /$ day as risk factors for reduced lung function (FEV1 $<60 \%$ ) in our cohort. Although the study population was relatively small, the results allowed us to take immediate action to improve patients' clinical status and outcome. The potentially modifiable factor affecting lung function-and thus, life expectancy - in these patients is BMI, which can be increased through weight gain interventions. Additionally, given that chronic Pseudomonas infection was also a risk factor for poor lung function, a strategy should be implemented to prevent infections, a supplementary monthly bacteriological examination was included in our practice in children with impaired lung function or low BMI. In summary, improvement of nutritional status and a more active lifestyle with infection prophylaxis are the primary treatment goals for our pediatric $\mathrm{CF}$ patient population.

\section{Acknowledgments}

The authors thank the patients and their parents for their participation in this study.

\section{Disclosure}

The authors report no conflicts of interest in this work.

\section{References}

1. Farrell PM. The prevalence of cystic fibrosis in the European Union. J Cyst Fibros. 2008;7(5):450-453. doi:10.1016/j.jcf.2008.03.007

2. Viviani L, Zolin A, Mehta A, Olesen HV. The European Cystic Fibrosis Society Patient Registry: valuable lessons learned on how to sustain a disease registry. Orphanet J Rare Dis. 2014;9:81,6-11. doi:10.1186/1750-1172-9-81 
3. Ratjen F, Döring G. Cystic fibrosis. Lancet. 2003;361 (9358):681-689. doi:10.1016/S0140-6736(03)12567-6

4. Ratjen F, Bell SC, Rowe SM, Goss CH, Quittner AL, Bush A. Cystic fibrosis. Nat Rev Dis Primers. 2015;1:15010.

5. Ciucă IM, Pop L, Tămaş L, Tăban S. Cystic fibrosis liver disease from diagnosis to risk factors. Rom J Morphol Embryol. 2014;55 (1):91-95.

6. Proesmans M, Vermeulen F, De Boeck K. What's new in cystic fibrosis? From treating symptoms to correction of the basic defect Eur J Pediatr. 2008;167(8):839-849. doi:10.1007/s00431-008-06932

7. Rosenfeld M, Sontag MK, Ren CL. Cystic fibrosis diagnosis and newborn screening. Pediatr Clin North Am. 2016;63(4):599-615. doi:10.1016/j.pcl.2016.04.004

8. Smyth AR, Bell SC, Bojcin S, et al. European cystic fibrosis society standards of care: best practice guidelines. J Cyst Fibros. 2014;13 (Suppl 1):S23-S42. doi:10.1016/j.jcf.2014.03.010

9. Flume PA, Mogayzel PJ, Robinson KA, et al. Cystic fibrosis pulmonary guidelines: treatment of pulmonary exacerbations. $\mathrm{Am}$ $J$ Respir Crit Care Med. 2009;180(9):802-808. doi:10.1164/ rccm.200812-1845PP

10. Gupta A, Urquhart D, Rosenthal M. Marked improvement in cystic fibrosis lung disease and nutrition following change in home environment. $J$ R Soc Med. 2009;102(Suppl 1):45-48. doi:10.1258/ jrsm.2009.s19010

11. Alvarez JA, Ziegler TR, Millson EC, Stecenko AA. Body composition and lung function in cystic fibrosis and their association with adiposity and normal-weight obesity. Nutrition. 2016;32(4):447-452. doi:10.1016/j.nut.2015.10.012

12. Kerem E, Viviani L, Zolin A, et al. Factors associated with FEV1 decline in cystic fibrosis: analysis of the ECFS patient registry. Eur Respir J. 2014;43(1):125-133. doi:10.1183/09031936.00166412

13. Konstan MW, Morgan WJ, Butler SM, et al. Risk factors for rate of decline in forced expiratory volume in one second in children and adolescents with cystic fibrosis. J Pediatr. 2007;151(2):134-139. doi:10.1016/j.jpeds.2007.03.006

14. Castellani C, Duff AJA, Bell SC, et al. ECFS best practice guidelines: the 2018 revision. $J$ Cyst Fibros. 2018;17(2):153-178. doi:10.1016/j.jcf.2018.02.006

15. Döring G, Flume P, Heijerman H, Elborn JS; Consensus Study Group. Treatment of lung infection in patients with cystic fibrosis: current and future strategies. J Cyst Fibros. 2012;11(6):461-479. doi:10.1016/j.jcf.2012.10.004

16. Kuczmarski RJ, Ogden CL, Guo SS, et al. 2000 CDC growth charts for the United States: methods and development. Vital Health Stat 11. 2002;246:1-190.40, 1324-1343.

17. Quanjer PH, Stanojevic S, Cole TJ, et al. Multi-ethnic reference values for spirometry for the 3-95-yr age range: the global lung function 2012 equations. Eur Respir J. 2012;40:1324-1343. doi:10.1183/09031936.00080312
18. Bacci G, Mengoni A, Fiscarelli E, et al. A different microbiome gene repertoire in the airways of cystic fibrosis patients with severe lung disease. Int J Mol Sci. 2017;18(8):1654. doi:10.3390/ijms18081654

19. Littlewood JM, Wolfe SP, Conway SP. Diagnosis and treatment of intestinal malabsorption in cystic fibrosis. Pediatr Pulmonol. 2006;41 (1):35-49. doi:10.1002/ppul.20286

20. Wilkes DL, Schneiderman JE, Nguyen T, et al. Exercise and physical activity in children with cystic fibrosis. Paediatr Respir Rev. 2009;10 (3):105-109. doi:10.1016/j.prrv.2009.04.001

21. Konstan MW, Butler SM, Wohl ME, et al. Growth and nutritional indexes in early life predict pulmonary function in cystic fibrosis. $J$ Pediatr. 2003;142(6):624-630. doi:10.1067/mpd.2003.152

22. Kastner-Cole D, Palmer CN, Ogston SA, Mehta A, Mukhopadhyay S. Overweight and obesity in deltaF508 homozygous cystic fibrosis. J Pediatr. 2005;147(3):402-404. doi:10.1016/j. jpeds.2005.06.003

23. Milla CE. Nutrition and lung disease in cystic fibrosis. Clin Chest Med. 2007;28(2):319-330. doi:10.1016/j.ccm.2007.02.006

24. Bell SC, Flume PA. Treatment decisions for MRSA in patients with cystic fibrosis (CF): when is enough, enough? Thorax. 2017;72:297-299. doi:10.1136/thoraxjnl-2016-209605

25. Dasenbrook EC, Merlo CA, Diener-West M, Lechtzin N, Boyle MP. Persistent methicillin-resistant Staphylococcus aureus and rate of FEV1 decline in cystic fibrosis. Am J Respir Crit Care Med. 2008;178(8):814-821. doi:10.1164/rccm.200802-3270C

26. Goss CH, Muhlebach MS. Review: staphylococcus aureus and MRSA in cystic fibrosis. J Cyst Fibros. 2011;10(5):298-306. doi:10.1016/j.jcf.2011.06.002

27. Vanderhelst E, De Meirleir L, Verbanck S, et al. Prevalence and impact on FEV1 decline of chronic methicillin-resistant Staphylococcus aureus (MRSA) colonization in patients with cystic fibrosis. A single-center, case control study of 165 patients. J Cyst Fibros. 2012;11(1):2-7. doi:10.1016/j.jcf.2011.08.006

28. Moran A, Dunitz J, Nathan B, Saeed A, Holme B, Thomas W. Cystic fibrosis-related diabetes: current trends in prevalence, incidence, and mortality. Diabetes Care. 2009;32(9):1626-1631. doi:10.2337/dc090586

29. Muhlebach MS, Miller M, LaVange LM, Mayhew G, Goodrich JS, Miller MB. Treatment intensity and characteristics of MRSA infection in CF. J Cyst Fibros. 2011;10(3):201-206. doi:10.1016/j. jcf.2011.02.004

30. Kelly A, Moran A. Update on cystic fibrosis-related diabetes. $J$ Cyst Fibros. 2013;12(4):318-331. doi:10.1016/j.jcf.2013.02.008
Journal of Multidisciplinary Healthcare

\section{Publish your work in this journal}

The Journal of Multidisciplinary Healthcare is an international, peerreviewed open-access journal that aims to represent and publish research in healthcare areas delivered by practitioners of different disciplines. This includes studies and reviews conducted by multidisciplinary teams as well as research which evaluates the results or conduct of such teams or healthcare processes in general. The journal

Submit your manuscript here: https://www.dovepress.com/journal-of-inflammation-research-journal covers a very wide range of areas and welcomes submissions from practitioners at all levels, from all over the world. The manuscript management system is completely online and includes a very quick and fair peer-review system. Visit http://www.dovepress.com/testimonials. php to read real quotes from published authors. 